\title{
Downstream hydraulic geometry for incised channels
}

\author{
N. A. Hadadin \\ Department of Civil Engineering, The Hashemite University, Jordan
}

\begin{abstract}
The DEC Project data was used to develop several regression relationships for incised channels (CEM Type IV or V). The shape factor that was developed for downstream hydraulic geometry regression analysis of CEM Types IV and V incised channel data is $\psi=29.39 S^{-0.114} d_{s}^{0.206}$. The shape factor $(W / d)$ is directly proportional to the bed material size and inversely proportional to the slope. The effect of discharge on the shape factor is negligible. The physical meaning of this equation is that small slopes and coarse grain sizes produce large width/depth ratios, and steep slopes and fine grain sizes produce small width/depth ratios. Two regression equations were developed for the hydraulic geometry for top width and mean depth with $95 \%$ upper and lower confidence interval for incised channels (CEM Types IV and V) in the DEC Project. There were minor differences between the exponents of flow discharge and channel slope between this study and the study of other investigators.

Keywords: shape factor, incised channel, hydraulic geometry, flow discharge, width depth ratio.
\end{abstract}

\section{Introduction}

Downstream hydraulic geometry deals with variation in a cross section along a stream, where cross-section form adjusts to accommodate the discharge and sediment load supplied from the drainage basin, within the additional constraints imposed by boundary composition, bank vegetation, and valley slope. A single channel-forming discharge is assumed to represent the channel morphology at a location, for various sites along the channel. Channel dimensions are not arbitrary but are adjusted, through the processes of erosion and deposition, to the quantity of water moving through the cross section so that the channel contains 
flow. Since discharge increases downstream with drainage area, width and mean depth should similarly vary Knighton [1].

Rhoads [2] described downstream hydraulic geometry analysis as an analysis of the bivariate relationship between channel parameters (such as width and depth) and an average or recurring discharge. Describing hydraulic properties of channel cross sections as a power function of flow depth was strongly supported by Garbrecht [3].

Julien [4] proposed four fundamental relationships of downstream hydraulic geometry of non-cohesive alluvial channels. He considered four fundamental concepts of hydraulics and sediments: flow continuity, flow resistance, longitudinal sediment mobility, and radial sediment mobility. Julien and Wargadalam [5] examined the downstream hydraulic geometry from a three-dimensional stability analysis of non-cohesive particles under twodimensional flows. They developed semi-theoretical equations, the hydraulic geometry relationship for mean depth $(\mathrm{m})$ and surface flow width $(\mathrm{m})$ are:

$$
\begin{aligned}
& d=0.20 Q^{\frac{2}{6 m+5}} d_{s} \frac{6 m}{6 m+5} S^{\frac{-1}{6 m+5}} \\
& W=1.330 Q^{\frac{4 m+2}{6 m+5}} d_{s}^{\frac{-4 m}{6 m+5}} S^{\frac{-(2 m+1)}{6 m+5}}
\end{aligned}
$$

where $Q \quad=$ flow discharge in $\left(\mathrm{m}^{3} / \mathrm{s}\right)$;

$$
\begin{aligned}
& d_{s}=d_{50}(\mathrm{~m}) ; \text { and } \\
& m=\frac{1}{\ln \frac{12.2 d}{d_{s}}}
\end{aligned}
$$

Huang and Nanson [6] studied the self-adjusting mechanism of alluvial channels. They found that by introducing a channel shape factor (width/depth), the self-adjusting mechanism of alluvial channels could be illustrated with the basic flow relationships of continuity, resistance, and sediment transport. They applied Lacey's flow [7] resistance and Duboys' sediment transport relationships [8]. For a stable canal and rectangular cross section they found that the width/depth ratio varies within a limited range (2.5 to 30 ).

Wolman [9] recognized that local variations in cross-sectional form are a possible source of scatter in downstream hydraulic geometry relationships. In particular, such variations can be related systematically to channel pattern and bed topography.

Knighton [1] documented that the dominant controls of channel form are discharge and sediment discharge, both of which integrate the effects of climate, vegetation, soils, geology, and other variables. However, Harvey [10] sought to correlate riffle spacing to channel geometry variables such as cross-sectional area, wetted perimeter, and channel width. Harvey concluded that the closest correlation exists in the relationship between riffle spacing and the widths associated with relatively frequent discharges, rather than the discharge of the channel bankfull width. 
Ackers [11] obtained a constant width/depth ratio for stable laboratory streams, using a small stream for his experimentation, he developed width and depth relationships in terms of discharge. The bed and bank materials used were sand with a median diameter that ranged between $0.16 \mathrm{~mm}$ to $0.34 \mathrm{~mm}$ and the discharge values ranged between 0.4 cubic feet per second (cfs) to $5.4 \mathrm{cfs}$. Sediment concentrations up to 400 parts per million (ppm) were observed.

A regime analysis of the data gave the following equations:

$$
\begin{aligned}
& W=3.6 Q^{0.42} \\
& d=0.28 Q^{0.43} \\
& \frac{W}{d}=12.9 Q^{-0.01}
\end{aligned}
$$

The width/depth ratio in Equation (5) is almost a constant and is equal to 12.9.

Schumm [12] studied the effects that the percentage of silt-clay (alluvial material smaller than $0.074 \mathrm{~mm}$ ) in the banks had on the shape of stream channels. He used a power function to relate the width/depth ratio to the percentage of silt-clay in the channel banks and found that downstream changes in width and depth are greatly influenced by sediment type, specifically that channels containing little silt-clay are relatively wide and shallow. The greater percentage of silt and clay in the perimeter produces a low width/depth ratio cross section, and coarser bed and bank material produces a high width/depth ratio cross section. Based on these considerations, Schumm presented empirical relationships for channel width, depth, meander, wavelength, and amplitude as functions of the amount of silt and clay and mean annual discharge or mean annual flood. Schumm [12] subdivided channels into three types on the basis of the dominant mode of sediment transport, using the percentage silt-clay $(M)$ in the channel boundary as his criterion:

Bed load channels $(M \leq 5)$;

Mixed-load channels $(5<M<20)$; and

Suspended-load (or wash load) channels ( $M \geq 20)$.

\section{Data sets collected for this study include}

Demonstration Erosion Control (DEC) Project Watson et al. [13].

The DEC Project currently includes 33 sites and a total of approximately $64 \mathrm{~km}$ of stream and 16 watersheds in the Yazoo River Basin in Mississippi. Many of the sites were channelized in the past and are now actively incising.

A total of 437 data sets at downstream hydraulic geometry were obtained from 7 incised streams (CEM Types IV and V) in the DEC Project. These data sets contain 2-year water discharge $\left(\mathrm{m}^{3} / \mathrm{s}\right)$, flow velocity $(\mathrm{m} / \mathrm{s})$, flow width $(\mathrm{m})$, flow depth $(\mathrm{m})$, mean bed diameter $(\mathrm{mm})$, and water surface slope $(\mathrm{m} / \mathrm{m})$,

The following streams in the DEC Project were used in the analysis Watson et al. [13]: 
Abiaca Creek, Site No. 6

Approximate watershed area at the downstream end of Site No. 6 is $257 \mathrm{sq} \mathrm{km}$ (99 sq mi). The thalweg profile and channel dimensions have been relatively constant since 1992.

Burney Branch

The study reach is $1,824 \mathrm{~m}(6,000 \mathrm{ft})$ long. Approximate watershed area at the downstream end of Burney Branch is $26 \mathrm{sq} \mathrm{km} \mathrm{(10} \mathrm{sq} \mathrm{mi).} \mathrm{A} 1997$ survey of the entire reach indicated widening with very little change in slope since 1995 . No significant changes were recorded in 2001.

Harland Creek, Site No. 1

Approximate watershed area at the downstream end of Site No. 1 is $70 \mathrm{sq} \mathrm{km} \mathrm{(27}$ sq mi). Harland Creek is a mixed, sand and gravel bed stream, exhibiting some of the original meandering tendency. The 2000 inspection provided clear evidence of a more stable reach that was originally visited in 1997. Some locations exhibited wetland vegetation in the bed of the stream. At the present time, it is unknown if the apparent stability is a result of reservoir control of peak discharges, or an artifact of a relatively low precipitation period.

Table 1: The range of values in the DEC Project data set (CEM Types IV and V) at downstream hydraulic geometry.

\begin{tabular}{|c|c|c|c|c|}
\hline $\begin{array}{l}\text { Hydraulic } \\
\text { Parameters }\end{array}$ & Minimum & Maximum & Mean & Median \\
\hline$Q_{2}\left(\mathrm{~m}^{3} / \mathrm{s}\right)$ & 27.2 & 75.4 & 48.7 & 50.7 \\
\hline$S(\mathrm{~m} / \mathrm{m})$ & 0.000156 & 0.0134 & 0.0018 & 0.00146 \\
\hline$d_{s}(\mathrm{~mm})$ & 0.33 & 0.51 & 0.416 & 0.38 \\
\hline$W(\mathrm{~m})$ & 7.6 & 46.0 & 21.03 & 20.1 \\
\hline$d(\mathrm{~m})$ & 0.7 & 2.77 & 1.67 & 1.71 \\
\hline
\end{tabular}

Hickahala Creek, Site No. 11

Site No. 11 is 1,216 m (4,000 ft) long, extending 1,216 m (4,000 ft) downstream of the County road bridge. Approximate watershed area at the downstream end of Site No. 11 is $26 \mathrm{sq} \mathrm{km}$ (10 sq mi). Upstream the channel is a CEM Type IV and downstream the channel is CEM Types III to IV.

Long Creek (2)

The Long Creek study reach is $2,432 \mathrm{~m}(8,000 \mathrm{ft})$ long, extending $1,824 \mathrm{~m}$ $(6,000 \mathrm{ft})$ upstream and $608 \mathrm{~m}(2,000 \mathrm{ft})$ downstream of the County road bridge that crosses Long Creek (2). This reach transitions from CEM Type $\mathrm{V}$ at the lower end to CEM Type II at the upper end. 
Perry Creek (1) and (2)

The study reach is $3,040 \mathrm{~m}(10,000 \mathrm{ft})$ long; Segment 1 is between river stations $0+00$ and 10+00; Segment 2 is between river stations $15+00$ and $50+00$. Approximate watershed area at the downstream end is $20.8 \mathrm{sq} \mathrm{km} \mathrm{(8} \mathrm{sq} \mathrm{mi).}$

Table 1 summarizes the range of hydraulic parameter values for the DEC Project data sets.

\section{Regression relationships}

Downstream hydraulic geometry relationships were expressed in the form of a power function of the dependent variables of $Q_{2}, S, d_{s}$ :

$$
X=a_{1} Q^{a_{2}} S^{a_{3}} d_{s}^{a_{4}}
$$

Coefficients $a_{1}, a_{2}, a_{3}$, and $a_{4}$ are determined from the regression model, and $X$ is either a mean flow depth or a mean flow width.

The regression relationships were linearized to the form:

$$
\log X=b+a_{2} \log Q+a_{3} \log S+a_{4} \log d_{s}
$$

where $b=\log a_{1}$.

The new empirical channel geometry equations for average flow depth, top width, and shape factor $(W / d)$, were developed using Microsoft Excel 2000 regression analysis. The results are shown in Tables 2 and 3.

Table 2: $\quad$ Regression summary for mean depth equation

\begin{tabular}{|l|r|r|r|l|r|r|}
\hline & Coefficients & Standard Error & \multicolumn{1}{c}{$t$ Stat } & P-value & \multicolumn{1}{c|}{ Lower 95\% } & Upper 95\% \\
\hline Intercept & -1.09075747 & 0.138588393 & -7.87048 & $2.86 \mathrm{E}-14$ & -1.363147268 & -0.81837 \\
\hline $\mathrm{Q}\left(\mathrm{m}^{3} / \mathrm{s}\right)$ & 0.37545459 & 0.019920454 & 18.84769 & $2.68 \mathrm{E}-58$ & 0.336301751 & 0.414607 \\
\hline $\mathrm{S}(\mathrm{m} / \mathrm{m})$ & -0.13995274 & 0.009490072 & -14.7473 & $3.58 \mathrm{E}-40$ & -0.158605087 & -0.1213 \\
\hline $\mathrm{d}_{\mathrm{s}}(\mathrm{m})$ & -0.08265133 & 0.039569819 & -2.08875 & 0.037314 & -0.160424187 & -0.00488 \\
\hline
\end{tabular}

Table 3: $\quad$ Regression summary for mean width equation.

\begin{tabular}{|l|r|r|r|r|r|r|}
\hline & Coefficients & Standard Error & $t$ Stat & P-value & Lower 95\% & Upper 95\% \\
\hline Intercept & 0.37747 & 0.210783515 & 1.790795 & 0.074025 & -0.0368164 & 0.79175635 \\
\hline $\mathrm{Q}\left(\mathrm{m}^{3} / \mathrm{s}\right)$ & 0.3702323 & 0.030297655 & 12.21983 & $1.04 \mathrm{E}-29$ & 0.31068353 & 0.42978112 \\
\hline $\mathrm{S}(\mathrm{m} / \mathrm{m})$ & -0.2542434 & 0.014433754 & -17.6145 & $9.29 \mathrm{E}-53$ & -0.2826123 & -0.22587443 \\
\hline $\mathrm{d}_{\mathrm{s}}(\mathrm{m})$ & 0.123692 & 0.060183002 & 2.055264 & 0.040453 & 0.00540473 & 0.24197917 \\
\hline
\end{tabular}

The new empirical channel geometry equations are:

Mean depth (m) -

$$
d=0.0811 Q_{2}^{0.375} S^{-0.140} d_{s}^{-0.083}
$$

Mean width (m) -

$$
W=2.385 Q_{2}^{0.370} S^{-0.254} d_{s}^{0.124}
$$


Shape factor $\psi-$

$$
\psi=\frac{W}{d}=29.39 Q_{2}^{-0.005} S^{-0.114} d_{s}^{0.206}
$$

where $Q_{2}=$ 2-year discharge $\left(\mathrm{m}^{3} / \mathrm{s}\right)$;

$d_{s}=\quad$ bed material median grain size $(\mathrm{m})$; and

$S=$ slope.

The flow discharge is eliminated from the shape factor equation because the exponent of flow discharge is very small $(-0.005)$, which is approximately equal to zero. The flow is an insignificant variable in prediction of the shape factor $(W / d)$ for downstream hydraulic geometry, however, flow is very significant for depth and is somewhat significant for width.

With elimination of the flow discharge from Equation (10), the equation of the shape factor $(\psi)$ becomes:

$$
\psi=\frac{W}{d}=29.39 S^{-0.114} d_{s}^{0.206}
$$

The regression summaries show that there are ranges of possible solutions of regression equations. The advantage of using confidence intervals $(95 \%$ upper level and 95\% lower level) is that these account for variability in regression constants and may be used to describe the variability and uncertainty in channel geometry.

The ranges of possible solutions of regression equations are as follows:

Mean depth (m) -

$$
d=(0.043) \text { to }(0.152) Q_{2}{ }^{(0.336) t o(0.415)} S^{(-0.159) t o(-0.121)} d_{s}{ }^{(-0.160) t o(-0.005)}
$$

Mean width (m) -

$$
W=(0.919) \operatorname{to}(6.191) Q_{2}^{(0.311) t o(0.430)} S^{(-0.283) t o(-0.226)} d_{s}^{(0.005) t o(0.242)}
$$

Shape factor $\psi=\frac{W}{d}-$

$$
\psi=(21.2) \operatorname{to}(40.75) S^{(-0.124) t o(-0.1046)} d_{s}{ }^{(0.166) t o(0.247)}
$$

Table 4 presents a comparison of regression relationships for incised channels for the DEC Project with downstream hydraulic geometry relationships developed by Huang and others (Huang and Warner [14]; Huang and Nanson $[6,15])$, and by Julien and Wargadalam [5]. There are minor differences between the exponents of flow discharge and channel slope. A discrepancy ratio between 0.5 and 2.0 was considered an acceptable range for determining the accuracy of computed flow depth and flow width to observed measurements Julien and Wargadalam [5]. Figures 1 and.2 show the comparison between prediction depth and width that was obtained from this study, Julien and Wargadalam [5], and from Huang and Nanson [16] with 437 data observations (DEC Project data). 
Table 4: Downstream hydraulic geometry relationships as a function of flow discharge and channel slope.

\begin{tabular}{|l|l|l|}
\hline $\begin{array}{l}\text { Huang and } \\
\text { Warner[14]; } \\
\text { Huang and } \\
\text { Nanson [[6], } \\
\text { and [15] }\end{array}$ & $W \propto Q^{0.501} S^{-0.156}$ & $d \propto Q^{0.299} S^{-0.206}$ \\
\hline $\begin{array}{l}\text { Julien and } \\
\text { Wargadalam } \\
\text { [5] }\end{array}$ & $W \propto Q^{0.4-0.5} S^{-(0.2-0.25)}$ & $d \propto Q^{0.4-0.25} S^{-(0.2-0.125)}$ \\
\hline $\begin{array}{l}\text { Huang and } \\
\text { Nanson [16] }\end{array}$ & $W \propto Q^{0.478} S^{0.076}$ & $d \propto Q^{0.289} S^{-0.350}$ \\
\hline $\begin{array}{c}\text { This } \\
\text { Study }\end{array}$ & $W \propto Q^{(0.311) t o(0.430)} S^{(-0.283) t o(-0.226)}$ & $d \propto Q^{(0.336) t o(0.415)} S^{(-0.159) t o(-0.121)}$ \\
\hline
\end{tabular}

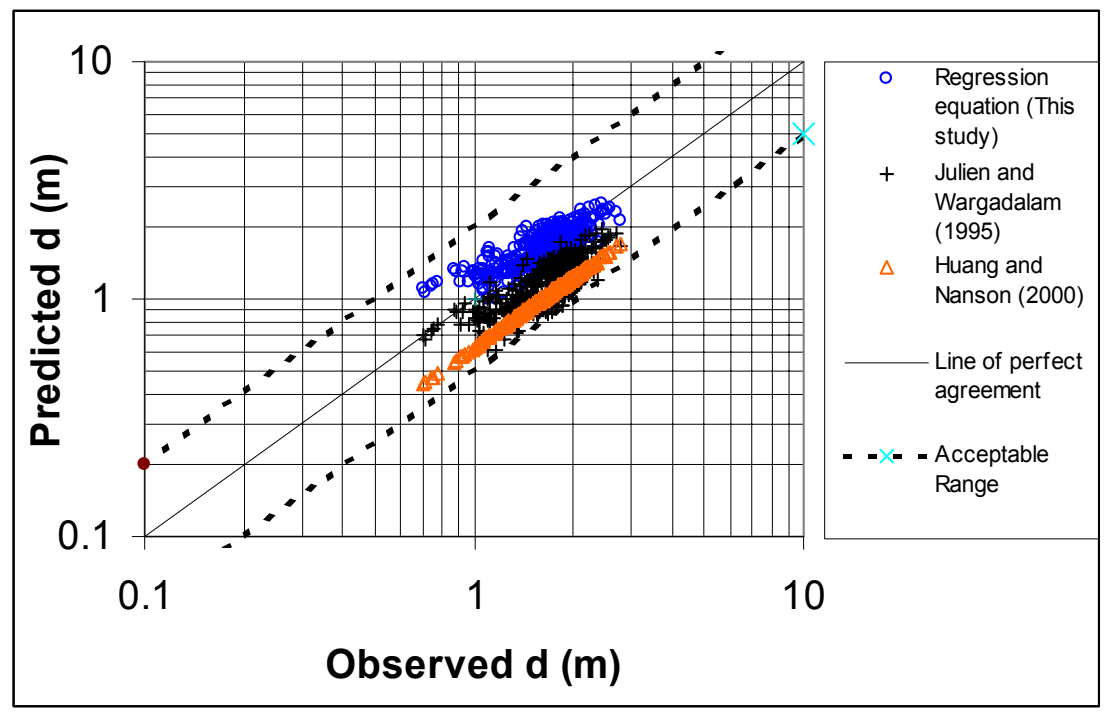

Figure 1: Comparison between observed depth of the 2 year discharge and predicted depth for DEC Project data.

As shown in Figure 1 there is a reasonable agreement (for regression depth) between the result of this study and Julien and Wargadalam's [5] results; however, the regression yields channel width less than Julien and Wargadalam's results, as shown in Figure 2. The results of the incised channel data analysis were compared with Huang and Nanson's [16] downstream hydraulic geometry equations, and the regression depth and width equations yielded greater channel 
depth and width than for Huang and Nanson's results. These results were expected, since DEC regression equations are for incised channels where the width/depth ratio was significantly affected by erosion-resistant clay bank channels.

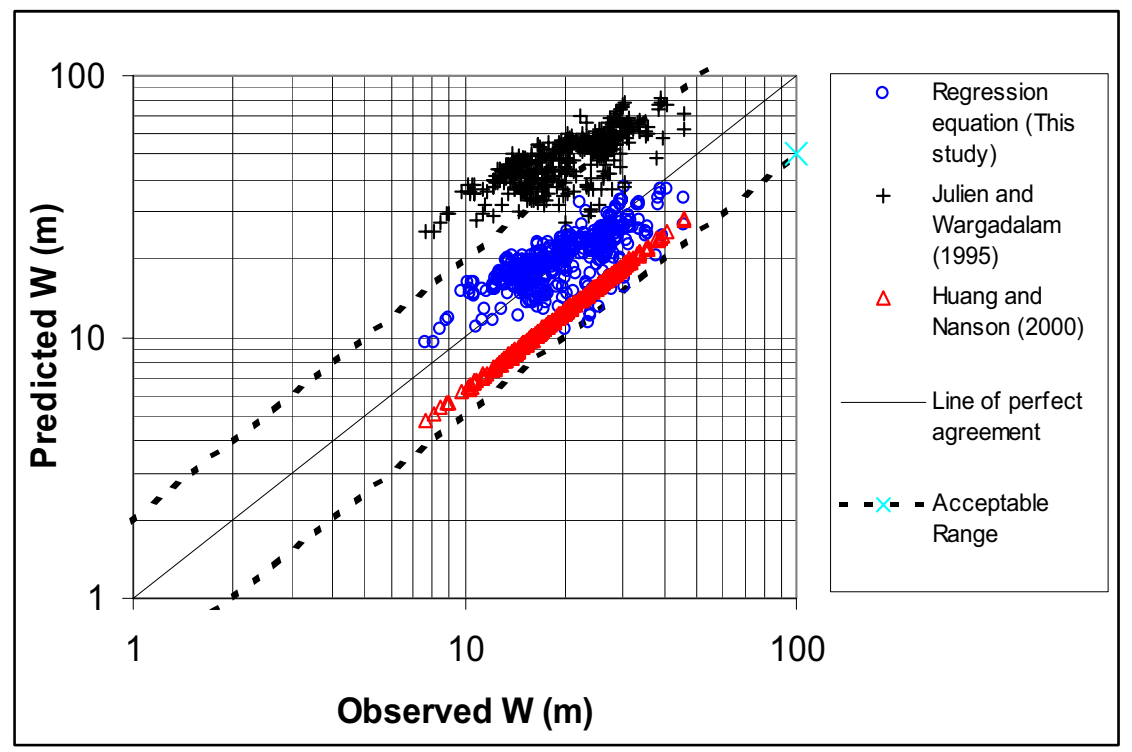

Figure 2: Comparison between observed width of the 2-year discharge and predicted width for DEC Project data.

\section{Conclusion}

The shape factor is directly proportional to the grain size and inversely proportional to the bed slope. The physical meaning is that low slope and coarse grain size produces a large width/depth ratio, and steep slope and fine grain size produces a small width/depth ratio. These results appear to be in agreement with Schumm [17] however, Schumm is based on the percentage of silt and clay in the perimeter, which includes forces, and channel responses that are gravitydriven mass wasting, and not hydraulic processes.

\section{List of symbols and Abbreviations}

$$
\begin{array}{lll}
a_{1}-a_{9}, \mathrm{~b} & = & \text { coefficients } \\
d & = & \text { flow depth }(\mathrm{m}) \\
d_{s} & = & \text { grain size } \\
m & = & \text { exponent of the theoretical hydraulic geometry equations }
\end{array}
$$




$\begin{array}{lll}M & = & \text { percentage silt-clay in the channel boundary } \\ P \text {-value } & = & \text { observed significance level of a statistical test } \\ Q & = & \text { flow rate }\left(\mathrm{m}^{3} / \mathrm{s}\right) \\ Q & = & \text { independent variable } \\ Q_{2} & = & \text { flow discharge at } 2 \text {-year recurrence interval } \\ S & = & \text { channel slope, energy slope, bed slope } \\ W & = & \text { channel top width at the water surface } \\ W / d & = & \text { width/depth ratio } \\ W / d & = & \text { shape factor } \\ X & = & \text { mean flow depth or mean flow width } \\ \psi & = & \text { non-dimensional channel shape factor; width-depth ratio }\end{array}$

\section{Abbreviations}

CEM Channel Evaluation Models

DEC Demonstration Erosion Control

\section{References}

[1] Knighton, A. D. (1998). Fluvial Forms and Processes: A New Perspective. New York, NY: John Wiley and Sons, 383 pp.

[2] Rhoads, B. L. (1991). A continuously varying parameter model of downstream hydraulic geometry. Water Resources Research, 27(8):18651872.

[3] Garbrecht, J. (1990). Analytical representation of cross-section hydraulic properties. J. Hydrology, 119:43-56.

[4] Julien, P. Y. (1988). Downstream hydraulic geometry of noncohesive alluvial channels. In: International Conference on River Regime, New York, NY: John Wiley and Sons, Inc., pp. 9-16.

[5] Julien, P. Y., and Wargadalam, J. (1995). Alluvial channel geometry: theory and applications. J. Hydraulic Engineering, ASCE, 121:312-325.

[6] Huang, H. Q., and Nanson, G. C. (1995). On a multivariate model of channel geometry. In: Proceedings of the XXVIth Congress of the International Association of Hydraulic Research, T. Telford, Ed., Vol. 1, pp. 510-515.

[7] Lacey, G. (1929-30). Stable channel in alluvium. Proceedings of the Institution of Civil Engineers, London, England, 229(Part 1):259-292.

[8] Duboys, P. (1879). Etudes du regime du Rhone et l'action exercee par les eaux sur un lit a fond de graviers indefiniment affouillable. Annales Des Ponts et Chaussees, 18(5):141-195. 
[9] Wolman, M.G. (1955). Factors influencing erosion of cohesive river bank. American J. Science, 257:385-395.

[10] Harvey, A. M. (1975). Some aspects of the relations between channel characteristics and riffle spacing of meandering streams. American J. Science, 275:470-478.

[11] Ackers, P. (1964). Experiments on small stream in alluvium. J. Hydraulic Division, ASCE, 90(HY4):1-37.

[12] Schumm, S. A. (1963). A tentative classification of alluvial river channels. U.S. Geological Survey Circular 477, Washington, DC: U.S. Department of the Interior, Geological Survey.

[13] Watson, C. C., Thornton, C. I., Carlson, K., Bledsoe, B. P., and Robeson, M. D. (2001). Demonstration erosion control monitoring, sites 2001 evaluation. Report to U.S. Army Corps of Engineers, Engineer Research and Development Center, Vicksburg, MS, $161 \mathrm{pp}$.

[14] Huang, H. Q., and Warner, R. F. (1995). The multivariate controls of hydraulic geometry; a causal investigation in terms of boundary shear distribution. Earth Surfaces Processes and Landforms, 20:115-130.

[15] Huang, H. Q., and Nanson, G. C. (1998). The influence of bank strength on channel geometry. Earth Surface Processes and Landforms, 23:865-876.

[16] Huang, H. Q., and Nanson, G. C. (2000). Hydraulic geometry and maximum flow efficiency as product of the least action. J. Surface Processes and Landform, 25:1-16.

[17] Schumm, S. A. (1960). The shape of alluvial channels in relation to sediment type. U.S. Geological Survey, Professional Paper 352-C, Washington, DC: U.S. Department of the Interior, Geological Survey, pp. 31-70. 